\title{
Using Seasonal Climate Variability Forecasts to Plan Forest Plantation Establishment 1
}

\author{
Norman Breuer, Matthew Langholtz, David Zierden, and Clyde Fraisse ${ }^{2}$
}

\section{Introduction}

Atmospheric scientists are now able to predict seasonal climate variations, with a relatively high level of skill. Knowledge of climatic conditions allows us to develop a seasonal management strategy for forest plantations and managed natural forests. Areas of application include seedling establishment, preparing for pests and diseases, fire management, harvest schedules and inventory management. This publication provides strategies to consider for pine plantation establishment in Florida and southern Alabama and Georgia. Seasonal climate conditions can be better predicted for this region because it is affected by the El Niño Southern Oscillation (ENSO) phenomenon.

Unlike weather prediction, where our time frame is no more than the up-coming week, climate forecasting can predict a wet, cool summer or a hot, dry winter. These types of forecasts refer to seasonal climate variability. Oscillations of the Pacific Ocean's sea surface temperature above and below normal are a major contributing factor in determining seasonal climate in the Southeastern United States.
Generally, the effect is stronger further south than north, and stronger in winter-spring than in summer-fall. Table 1 summarizes seasonal variations in the Southeast.

It is important to distinguish that this fact sheet proposes forest management options in light of improved climate prediction, and as such has implications for the six-month to one year planning horizon. Management options described here are not pertinent to the daily or weekly operational planning as may be influenced by weather prediction.

Information about the current El Niño/La Niña status and the implications for Florida climate are provided by The Southeast Climate Consortium and can be found on the Web at <www.agclimate.org>, and at a related weather site, $<$ http://fawn.ifas.ufl.edu>.

\section{Plantation Establishment}

There are three main types of regeneration: natural regeneration, direct seeding and planting. (See EDIS CIR759 for more information about these regeneration techniques.) As most forest regeneration

1. This document is ABE354, one of a series of the Agricultural and Biological Department, Florida Cooperative Extension Service, Institute of Food and Sciences, University of Florida. Published November 2004. Please visit the Web site at http://edis.ifas.ufl.edu.

2. Norman Breuer, Southeast Climate Consortium; Mathew Langholtz, School of Forest Resources and Conservation, University of Florida; David Zierden; The Center for Ocean-Atmospheric Prediction Studies (COAPS); and Clyde Fraisse, Assistant Extension Scientist, Dept. of Agricultural and Biological Engineering, University of Florida.

The Institute of Food and Agricultural Sciences (IFAS) is an Equal Employment Opportunity - Affirmative Action Employer authorized to provide research, educational information and other services only to individuals and institutions that function without regard to race, creed, color, religion, age, disability, sex, sexual orientation, marital status, national origin, political opinions or affiliations. For information on obtaining other extension publications, contact your county Cooperative Extension Service office. Florida Cooperative Extension Service / Institute of Food and Agricultural Sciences / University of Florida / Larry R. Arrington, Interim Dean 
in the Southern U.S. is planted, we focus on the implications of climate prediction on forest plantation establishment (planting), though the concepts are likely to apply to natural regeneration and direct seeding as well.

Successful plantation establishment is critical to profitable forestry. In 1999-2000 plantings, a drought in many areas of the Southeast caused by La Niña led to high seedling death and disease. Losses were large and are reflected in the poor quality of those stands today. In contrast, 1998 (El Niño-rainy) plantings were well established.

Aspects of plantation establishment that may be adjusted according to seasonal climate prediction include:

- Planting Scheduling: A landowner might schedule plantings to coincide with El Niño (wet) winters. With prediction of a La Niña (dry) winter when seedlings are more likely to die, a landowner could choose to reschedule planting to another season or plant in low areas where soil moisture is more available.

- Planting Density: With prediction of a moderate La Niña (dry) winter, a landowner could plant at a higher density to compensate for anticipated seedling mortality.

- Weed control: Following planting during an El Niño winter, increased growth of competing vegetation could call for weed control (see Campbell and Long 1998).

For complete information about plantation establishment in the Southeast U.S., see:

- Campbell, P., A. Long. 1998. Vegetation Management in Florida's Private Non-Industrial Forests. IFAS Publication SS-FOR-10, available on the Web at:

$<$

http://edis.ifas.ufl.edu/pdffiles/FR/FR04400.pdf>

- Duryea, M. 2000. Forest Regeneration Methods: Natural Regeneration, Direct Seeding and Planting. IFAS Publication CIR759, available on the Web at:

$<$

http://edis.ifas.ufl.edu/pdffiles/FR/FR02400.pdf>
- Duryea, M.L. and J.C. Edwards. 1997

(Revised). Planting Southern Pines. IFAS, University of Florida, Cooperative Extension Service. Circular 767. 14p. Available on the Web at:

$<$

http://edis.ifas.ufl.edu/pdffiles/FR/FR02500.pdf>

- USDA Forest Service. 1989. A Guide to Care and Planting of Southern Pine Seedlings. USDA Forest Service Management Bulletin RB-MB39. $44 p$. 
Table 1. How ENSO Phases Influence Conditions in Alabama, Florida and Georgia

\begin{tabular}{|c|c|c|c|c|c|}
\hline \multirow[t]{2}{*}{ Phase } & \multirow{2}{*}{ Region } & & & & \\
\hline & & Oct-Dec & Jan-Mar & Apr-Jun & Jul-Sep \\
\hline \multirow[t]{4}{*}{ El Niño } & $\begin{array}{l}\text { Peninsular } \\
\text { Florida }\end{array}$ & Wet - cool & Wet-Cool & Slightly Dry & $\begin{array}{l}\text { Slightly dry to } \\
\text { none }\end{array}$ \\
\hline & $\begin{array}{l}\text { Panhandle-tri } \\
\text { state area }\end{array}$ & Wet & Wet & Slightly Wet & None \\
\hline & $\begin{array}{l}\text { Western } \\
\text { Panhandle }\end{array}$ & None & Wet & Slightly Dry & None \\
\hline & $\begin{array}{l}\text { Central and } \\
\text { North } A L, G A\end{array}$ & None & None & None & Slightly dry \\
\hline \multirow[t]{4}{*}{ La Niña } & $\begin{array}{l}\text { Peninsular } \\
\text { Florida } \\
\end{array}$ & $\begin{array}{l}\text { Dry } \\
\text { Slightly Warm }\end{array}$ & & & \\
\hline & $\begin{array}{l}\text { Panhandle-tri } \\
\text { state area }\end{array}$ & Weak dry & Dry & Dry & None \\
\hline & $\begin{array}{l}\text { Western } \\
\text { Panhandle }\end{array}$ & Slightly Dry & Dry & Dry & None \\
\hline & $\begin{array}{l}\text { Central and } \\
\text { North AL, GA }\end{array}$ & Dry & $\begin{array}{l}\text { Dry in South, } \\
\text { wet in NW AL }\end{array}$ & None & Wet in NW AL \\
\hline Neutral & & None & None & None & None \\
\hline
\end{tabular}

